\title{
EFFECT OF CROPPING SYSTEMS AND NITROGEN FERTILIZATION LEVELS ON GROWTH AD YIELD OF GIZA 168 WHEAT CULTIVAR \\ El-Genbeehy, M.M. ${ }^{1}$; Soheir M.H. Abd Allah ${ }^{2}$ and \\ SH.R. Abd El-Zaher ${ }^{32}$ \\ 1- Crop. Sci. Dept., Fac. of Agric., Alex Univ. \\ 2- Field Crops Res. Institute, ARC, Egypt.
}

\begin{abstract}
Two field experiments were carried out during the two successive seasons of 2005/06 and 2006/07 at Agricultural Research Station, Faculty of Agriculture, Alexandria University, to evaluate Giza 168 wheat cultivar response to different cropping systems and nitrogen fertilizer levels. The results indicated that, cropping systems including one cut type berseem and/ or soybean significantly decreased weeds dry weight and increased number of tillers and spikes per square meter, 1000grain weight and grain yield per feddan in the two seasons. Increasing nitrogen levels up to $80 \mathrm{~kg}$ per feddan, significantly decreased weeds dry weight and increased plant height, number of tillers and spikes per square meter, spike length, grain weight, number of grains per spike, 1000- grain weight and grain yield per feddan in both seasons. Application of $80 \mathrm{~kg} \mathrm{~N} /$ fed. to the cropping systems containing leguminous crops especially the one cut berssem and soybean produced the heaviest grains, highest number of tillers per square meter and grain yield per feddan in the first, second and both seasons, respectively.
\end{abstract}

Keywords: Cropping system, Nitrogen level, Weed dry weight, Bread wheat, Grain yield.

\section{INTRODUCTION}

Wheat is an important cereal crop in Egypt. To attain food self sufficiency, there is much need to maximize wheat yield capacity. Ideal wheat production requires the application of appropriate cultural decision of which crop positioning in crop sequence, optimum nitrogen rate and better weed control are a few.

It is well known that weeds negatively affect crop development and yield according to the crop weed degree of competition which is influenced by different factors such as crop morphology and physiology, growth resources, especially nitrogen application level and cultural practices such as nitrogen rate. Enhanced competitive ability of wheat against weeds has been attributed to wheat greater tillering capacity (Champien et al., 1998) and early ground cover (Das and Yaduraju, 1999). Furthermore, wheat has the ability to control weeds through the release of phototoxic compounds that have inhibitory effect on weed plants.

Residues of narrow $\mathrm{C} / \mathrm{N}$ ratio (below 20:1, as berseem) increase $\mathrm{N}$ immobilization by microbial organism that are important to increase $\mathrm{N}$ availability and uptake by wheat plants. The reverse is valid when residues have $\mathrm{C} / \mathrm{N}$ ratio above 20:1, such as grain and fodder maize (Jones, 1987). 
The value of legumes inclusion in sequential cropping systems has been attributed to the contribution they make to the following crop (soil supply with organic matter and available organic $\mathrm{N}$ ) and reduction of its reliance on chemical $\mathrm{N}$ fertilizers (Echeverria et al., 1992). Soybean, despite being a legume crop, is usually considered a soil self destructive crop where it removes most of the $\mathrm{N}$ fixed by its harvested portions to leave soil with very little residual N (Mc Coll, 1989 and Kupper, 2002). Nevertheless, Prasad and Kerketta (1991) reported that inclusion of forage legume crop, in cropping sequences, is associated with soil supply with more amount of organic material and organic $\mathrm{N}$.

Wheat grain yield is the product of three components: number of spikes/ $\mathrm{m}^{2}$, number of grains/ spike and grain weight. A strong tendency towards mutual compensation is usually observed among these components and this tends to minimize yield loss when one component is reduced. Reports by Ercoli and Masoni (1995), EL-Eryani (2001) and Khalil and ELGenbeehy (2004) indicated that there was a decline in either or both of number of grains/ spike and individual grain weight with increasing number of spikes/ $\mathrm{m}^{2}$ as nitrogen rate increased.

The present work was carried out to study the effect of four cropping systems and three nitrogen levels on weeds dry weight, wheat growth, yield and its attributes.

\section{MATERIALS AND METHODS}

Two field experiments were conducted at the Agricultural Research Station, Faculty of Agriculture, Alexandria University during the two successive seasons of 2005/06 and 2006/07, systems to study the effect of four cropping [maize-wheat $\left(S_{1}\right)$, maize-one cut berseem-wheat $\left(S_{2}\right)$, sunflower-fodder maize-wheat $\left(S_{3}\right)$ and soybean-one cut berseem-wheat $\left(\mathrm{S}_{4}\right)$ ] and three $\mathrm{N}$ levels $(40,60$ and $80 \mathrm{~kg} / \mathrm{fed})$ on growth, yield and its attributes of Giza 168 wheat cultivar and the response of wheat characters besides weed interference. Nitrogen, as ammonium nitrate (33.5\%) was added to wheat in two equal doses (at first and second irrigations). As an average of the two seasons, soil chemical properties of the experimental site were, $8.2,1.1 \%$ and $35 \mathrm{ppm}$ for $\mathrm{pH}$, total organic matter and available nitrogen, respectively. Crops cultivars were Giza 168, three-way cross 310 , three-way cross 310 (hold house seeds), Giza 53, and Giza 83, respectively, for wheat, maize, fodder maize, sunflower and soybean crops along with ALFahl cultivar as one cut berseem. A split plot design with three replications was used in both seasons with the allocation of cropping systems and $\mathrm{N}$ levels to the main and sub plots, respectively. The main plot comprised 10 ridges, each $3 \mathrm{~m}$ long and $0.7 \mathrm{~m}$ wide $\left(\frac{1}{200}\right.$ fed. $)$. Before wheat planting, each plot was divided into three equal sub plots $6.3 \mathrm{~m}^{2}$ area $(3 \mathrm{~m}$ long and $2.1 \mathrm{~m}$ wide), where each sub plot was prepared using rotary hoe and hand-leveled. Wheat seeds were drilled in rows (at recommended seeding rate of $60 \mathrm{~kg} /$ fed.) at within rows spacing of $0.3 \mathrm{~m}$ (7 rows/ sub plot). Respective planting 
dates in the two seasons were: 5 and 10 May for maize and soybean, 10 and 15 April for sunflower, 15 and 20 September for berseem and 15 and 20 November for wheat. All cultural practices were applied as recommended.

Heading date (H.D) was recorded as the number of days from sowing to $50 \%$ of spikes completely emerged from flag leaf in each sub-plot.

At harvest, a survey of the dominating narrow-and broad-leaved weeds (from a quadrate $1.0 \times 0.6 \mathrm{~m}$ ) in the experimental site, in both seasons, was carried out to study the preceding crop effect on weed population in wheat fields. Broad leaves included field bindweed (Convolvuls arvensis), yellow sweet clover (Melilotus indicus) and vetch (Vicia sativa). The narrow-leave weeds included canary grass (Phalaris canariensis), wild oats (Avena fatua) and darnel (Lolium temulentum). Dry weight of both weeds types was obtained through oven-drying at $70^{\circ} \mathrm{C}$ for 48 hours and reached to constant weight.

At harvest, also, ten guarded plants were randomly taken from each sub-plot to determine, the following traits: plant height $(\mathrm{cm})$, spike charcters (length $(\mathrm{cm})$, number of grains, spikelets number and spike grain weight $(\mathrm{g})$ ), and 1000-grain weight $(\mathrm{g})$ number of spikes $/ \mathrm{m}^{2}$, straw and grain yields were determined by harvesting all plants of each plot and threshed, straw and grain were weighted, then converted to tons and ardabs/ fed., respectively.

Statistical analysis of data including analysis of variance and comparison between means using L.S.D. at 0.05 level probability for each of the studied traits was applied according to Gomez and Gomez (1984). From the center of each plot one square miter were counted to measure the number of spikes $/ \mathrm{m}^{2}$.straw and grain.

\section{RESULTS AND DISCUSSION}

Means of wheat characteristics in the two seasons are presented in Tables (1 and 2). Response to cropping patterns were significant in both seasons for weeds dry weight, number of tillers and spikes/ $\mathrm{m}^{2}, 1000$-grain weight and grain yield/ fed. Data further showed that weeds dry weight, plant height, number of tillers and spikes/ $\mathrm{m}^{2}$, spike length, spike grain weight, number of grains/ spike, 1000-grain weight and grain yield/ fed. were significantly affected by nitrogen levels in both seasons. In addition, no interaction effects of cropping patterns and nitrogen rates were found in all studied characters except number of tillers/ $\mathrm{m}^{2}$ (in the second season), 1000grain weight (in the first season) and grain yield/ fed. (in both seasons) which are presented in Table (3).

The obtained results will be presented as follows:

\section{Effect of cropping systems:}

Variations in weeds dry weight (Table 1) were significant in both seasons, where weed biomass was lower under cropping systems that included ALFahl berseem $\left(S_{2}\right.$ and $\left.S_{4}\right)$ due to greater weeds removal with berseem cutting and positive wheat competition with weeds afterwards. Increasing in organic $\mathrm{N}$ availability and wheat initial growth decreased, weeds leaf area and photoassimilates production and accumulation enabling wheat 


\section{El-Genbeehy, M.M. et al.}

to compete and suppress of weeds growth through shading associating with weeds greatest suppression. 
J. Agric. Sci. Mansoura Univ., 34(1), January, 2009

1

325 
El-Genbeehy, M.M. et al.

2 
Table (3): Means of numbers of tillers/ $\mathrm{m}^{2}, 1000$-grain weight and grain yield/ fed. affected by cropping systems $\times$ nitrogen levels interactions in the second season, first and both season, respectively:

\begin{tabular}{|c|c|c|c|c|c|c|c|c|c|c|c|c|}
\hline \multirow{3}{*}{ Treatments } & \multirow{2}{*}{\multicolumn{3}{|c|}{$\begin{array}{c}\text { No. of tillers/ } \mathrm{m}^{2} \\
2006 / 2007\end{array}$}} & \multirow{2}{*}{\multicolumn{3}{|c|}{$\begin{array}{l}\begin{array}{l}1000-g r a i n \\
\text { weight }(g)\end{array} \\
2005 / 2006\end{array}$}} & \multicolumn{6}{|c|}{ Grain yield (Ardab/ fed.) } \\
\hline & & & & & & & \multicolumn{3}{|c|}{$2005 / 2006$} & \multicolumn{3}{|c|}{$2006 / 2007$} \\
\hline & 40 & 60 & 80 & 40 & 60 & 80 & 40 & 60 & 80 & 40 & 60 & 80 \\
\hline \\
\hline \multirow{2}{*}{\multicolumn{13}{|c|}{ 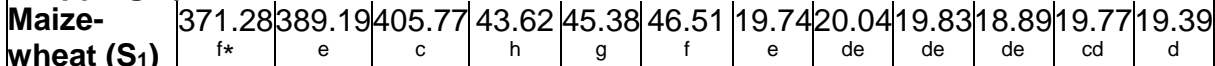 }} \\
\hline & $f$ & e & c & $\mathrm{h}$ & g & & e & $\mathrm{de}$ & de & de & & $d$ \\
\hline \multicolumn{13}{|c|}{ Maize-B- 386.} \\
\hline Wheat $\left(\mathbf{S}_{2}\right)$ & e & c & 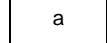 & $d$ & . & 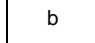 & d & c & b & de & b & bc \\
\hline \multirow{5}{*}{$\begin{array}{l}\text { Sun-Fom- } \\
\text { Wheat }\left(\mathrm{S}_{3}\right) \\
\text { So-B- } \\
\text { Wheat }\left(\mathrm{S}_{4}\right) \\
\text { L.S.D.0.05 }\end{array}$} & 374.49 & 388.48 & 3405.60 & $43.68^{h}$ & 47.89 & 48.83 & 19.50 & 20.06 & 19.72 & \multirow{2}{*}{$\begin{array}{c}18.89 \\
\mathrm{de}\end{array}$} & 19.34 & \multirow{2}{*}{$e_{e}^{18.74}$} \\
\hline & $f$ & e & c & & e & d & e & de & e & & d & \\
\hline & 398.24 & 416.44 & 4439.83 & 51.90 & 53.79 & $54.60^{\circ}$ & 21.18 & 21.07 & 23.1 & 20.06 & 18.85 & 23.34 \\
\hline & & 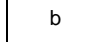 & 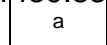 & & $\mathrm{b}$ & & 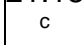 & c & a & . & de & 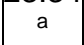 \\
\hline & & 4.94 & & & 0.79 & & & 0.62 & & & 0.57 & \\
\hline
\end{tabular}

Fom = fodder maize, B = one cut berseem , Sun = Sunflower , So = Soybean

* Means within the same column followed by the same letter(s) are not significantly different according to L.S.D. at $\mathbf{0 . 0 5}$ probability level.

Increasing in non legumes ratios in crop sequence before wheat $\left(S_{1}\right.$ and $S_{3}$ ) caused weed biomass to be increased. The most found weeds were leguminous ones, each of greater biomass/ plant than that of the grasses associate, which occurred the increase of weed biomass in case of $S_{1}$ and $S_{3}$ systems. As discussed data declared that sequences do not containing berseem-one cut type $\left(S_{1}\right.$ and $\left.S_{3}\right)$ exceeded the other two systems in weed biomass by $59.69 \mathrm{~g}$ as an average of the two seasons.

The effect of different crops, which proceeded wheat, on number of tillers/ $\mathrm{m}^{2}$ was significant in both seasons (Table 1). Such trait was affected by the presence or/ and the frequency of leguminous crops in crop sequence. Data revealed that crop sequence of soybean and one cut type berseem, followed by sequence including berseem only, produced the highest number of tillers. On the other hand, the absence of leguminous crops in the crop sequence resulted the lowest values of such trait.

Decay of residues narrow in $\mathrm{C} / \mathrm{N}$ ratio in addition to nitrogen fixation by legumes is associated with soil greater content from available $\mathrm{N}$ and the more translocation of $\mathrm{N}$ to the following wheat increasing shoot growth, i.e., number of tillers $/ \mathrm{m}^{2}$, as a result of greater assimilates productivity (Gardener et al., 1985). These results agreed with the conclusion of Nawar and Khalil (2003) which documented that the after harvesting residues of wheat- Alfahl berseem mixture increased wheat tillering, compared to wheat residues when grown alone.

Response of spike number per square meter was significant as affected by the different cropping systems in the two seasons of study (Table 1). Legumes are known to increase soil fertility, especially soil $\mathrm{N}$ and organic matter, and to improve soil physical properties and, consequently, to enhance the growth of the succeeding wheat crop that produced greater number of 
spikes/ $\mathrm{m}^{2}$ in the second and fourth sequences, compared to the remaining two sequences (Holland and Herridge, 1992). Increases in legume percent for the $\mathrm{S}_{4}$ pattern caused wheat to produce the maximum number of spikes/ $\mathrm{m}^{2}$ and was statistically similar to $\mathrm{S}_{2}$ system in this respect.

Meanwhile, sequences of non legumes $\left(S_{1}\right.$ and $\left.S_{3}\right)$ gave less number of spikes/ $\mathrm{m}^{2}$ indicating that the preceding non-legumes exploited more soil growth factors thus decreasing their availability to the following wheat resulting in decreasing number of ear-bearing tillers. It is interesting to note that there is a positive relevance between such trait and number of tillers $/ \mathrm{m}^{2}$, where the maximum and minimum records of tillers and spikes number/ $\mathrm{m}^{2}$ were attained from sequences of legumes and non legumes inclusion, respectively.

The analysis of data further showed that preceding crop significantly affected the following wheat regarding one thousand grain weight in both seasons (Table 1). The highest value of this trait was associated with the second and fourth sequences (in which berseem one-cut type was included), whereas, the least one was obtained from the first and third sequences of non leguminous preceding crops. Nawar and Khalil (2003) and Khalil and ELGenbeehy (2004) reported similar findings.

The results obtained for grain yield/ fed. indicated the significant response of wheat to the preceding crops in both seasons (Table 2). These results, also, revealed that the sequences of legumes produced the maximum grain yield, however, the minimum one was obtained from sequences of non legumes. The relative increase in grain yield of wheat ranged from 9.3 to $10.9 \%$, as an average of the two seasons, from the third to fourth sequence.

These results were attributed to the good residual effect of legumes on soil fertility, greater $\mathrm{N}$ uptake and conversion into photoassimilates, resulting in the increase of a single grain weight and grain yield/ fed.

\section{Effect of nitrogen levels:}

Weeds dry weight in wheat was significantly affected by nitrogen fertilization levels in both seasons (Table 1). Data showed that increasing nitrogen levels from 40 to $80 \mathrm{~kg} / \mathrm{fed}$. led to a decrease in weeds dry weights by 13.87 and $12.29 \mathrm{~g}$ per 0.06 square meter in the first and second seasons, respectively.

Such result is attributed to more light interception by wheat plants, with less light penetration to be under the level of weed growth (Champien et al., 1998).

In addition, the weeds maximum dry matter was obtained from the lowest nitrogen rate. Greater light use efficiency as a result of more light penetration into plant canopy, due to reduced wheat growth under lower than optimum $\mathrm{N}$ levels, increased weeds growth and competitive ability for soil growth factors enhancing the weed positive feed back.

On the contrary, increasing nitrogen application up to $80 \mathrm{~kg} / \mathrm{fed}$. significantly increased both wheat plant height by 7.32 and $6.82 \mathrm{~cm}$ and number of tillers by 46.5 and 39 tiller per meter square in the two successive seasons, respectively. Increasing both traits decreased light penetration to weed plants and subsequently reduced the photosynthesis and accumulation of dry matter in weed plants. These results agreed with those obtained by 
Abo-Shataia et al., 2001, Pandey et al., 2001; Maqsood et al., 2002; Abdul Galil et al., 2003; Ahmed, 2005 and Sieling et al., 2005.

With regard to number of spikes per square meter (Table 1), increasing nitrogen fertilization up to $80 \mathrm{~kg} / \mathrm{fed}$. significantly increased this trait by 9.0 and $10.3 \%$ compared to $40 \mathrm{~kg} \mathrm{~N} /$ fed. in the two seasons, respectively. Abd Allah (1996), EL-Genbeehy et al. (2001), Maqsood et al. (2002), Ahmed (2005) and Sieling et al. (2005) obtained similar results.

Data in (Table 2) showed that spike length was significantly increased with increasing nitrogen fertilizer rate up to $80 \mathrm{~kg} / \mathrm{fed}$. The highest nitrogen rate produced the tallest spikes $(11.84$ and $12.76 \mathrm{~cm})$ in the two successive seasons, however spike lengths resulting from 60 and $80 \mathrm{~kg} \mathrm{~N} /$ fed. were statistically equal in the second season.

The same trend of results was obtained for spike grain weight and number of grains per spike, where the highest nitrogen level produced the heaviest spikes (1.977 and $1.775 \mathrm{~g}$ ) and more grains per spike (43.93 and 38.20 ) in the two seasons, respectively. Many researchers pointed out the same trend (Shalaby et al., 1996; Sharaan and Abd EL-Samie, 1999; ELEryani, 2001; Abd EL-Dayem, 2003 and Ahmed, 2005).

With respect to 1000-grain weight, data in (Table 2) revealed that there was a gradual increase in this trait with increasing nitrogen fertilization levels in both seasons. The heaviest kernels (50.74 and $52.93 \mathrm{~g} / 1000$ grain) in the two successive seasons resulted from $80 \mathrm{~kg} \mathrm{~N} / \mathrm{fed}$. application. This may be due to the encouraging effect of nitrogen on photoassimilates production and accumulation in kernel. Similar results were obtained by Abd Allah (1996), Hassan and Gaballah (2000), EL-Genbeheey et al. (2001), Maqsood et al. (2002) and Ahmed (2005).

As for grain yield, data in (Table 2) revealed that increasing nitrogen rates up to $80 \mathrm{~kg} / \mathrm{fed}$. increased grain yield (1.22 and $1.40 \mathrm{ardab} / \mathrm{fed}$.) compared to $40 \mathrm{~kg} \mathrm{~N} / \mathrm{fed}$. in the first and second seasons, respectively, these increases are considered as a result of increase the three yield attributes, i.e. number of spikes per square meter, number of grains per spike and 1000-kernel weight. These results agreed with those obtained by Behera et al. (2000), Olsen et al. (2000), Ehdaie et al. (2001), Maqsood et al. (2002), Abdul Galil et al. (2003), Boehm et al. (2004), Ahmed (2005) and Sieling et al. (2005).

\section{Effect of cropping systems $\times$ Nitrogen levels Interactions:}

Data in (Table 3) showed that cropping systems $\times$ nitrogen levels interactions had significant effects on number of tillers per square meter, 1000 -grain weight and grain yield per feddan in the second, first and both seasons, respectively.

Mean number of tillers per square meter was significantly increased by increasing nitrogen levels under any of the four cropping systems. The lowest tillers numbers (371.28 and 374.49) resulted from the first and third cropping systems under the lowest nitrogen level $(40 \mathrm{~kg} \mathrm{~N} /$ fed.), respectively. Conversely, application of the highest nitrogen level $(80 \mathrm{~kg} / \mathrm{fed})$ to the second and fourth cropping systems produced the highest tillers numbers (435.71 and 439.83), respectively. These results might be due the value of legumes on the following crop as soil suppliers with organic matter and 
available organic nitrogen and subsequent reduction of wheat reliance on chemical nitrogen fertilizer (Echeverria et al., 1992).

Interaction of the two studied factors had significant effect on 1000grain weight in the first season by the same way of tillers number per square meter. Increasing nitrogen fertilization rates under any of the cropping systems especially those including the legumes, produced the heaviest grains. Cropping systems including only cereal crops (first and third) at the lowest nitrogen level produced the lightest kernels (43.62 and $43.68 \mathrm{~g} / 1000$ grain), respectively, however the other two cropping systems which contained one or two leguminous crops (second and fourth) produced the heaviest kernels $(54.60,53.79$ and $53.02 \mathrm{~g} / 1000$ grain) under 80 or $60 \mathrm{~kg} \mathrm{~N} /$ fed. Prasad and Kerketta (1991) reported that inclusion of forage legumes in the cropping sequence is associated with soil supply with more amount of organic matter and nitrogen

With regard to interaction effects on grain yield in the first and second seasons, increasing nitrogen fertilizer, in general, increased grain yield in all cropping systems and the highest grain yield (23.15 and $23.34 \mathrm{ardab} / \mathrm{fed}$ ) was realized from the fourth cropping system treated with $80 \mathrm{~kg} \mathrm{~N} / \mathrm{fed}$ in the two successive seasons, followed by the second system with $80 \mathrm{~kg} \mathrm{~N} /$ fed (22.02 ardab) in the first season and 60 and $80 \mathrm{~kg} \mathrm{~N} / \mathrm{fed}(20.96$ and 20.52 ardab/ fed), respectively, in the second one. In contrast, the first and third cropping systems produced the lowest grain yields under any of the nitrogen levels application. These results were expected since both cropping systems, which contained the leguminous crops, with increasing nitrogen fertilization produced the highest yield components i.e., number of spikes per square meter, number of grains per spike and 1000-kernel weight.

\section{REFERENCES}

Abd Allah, Soheir.M.H. 1996. Studies on wheat crop: Effect of nitrogen fertilizer level and time of application on yield and plant grain characteristics. M. Sc. Thesis, Faculty of Agriculture, Alexandria University, Egypt.

Abd EL-Dayem, S.M.A. 2003. Evaluation of wheat genotypes for productivity under nitrogen levels and seeding rates. Ph.D. Thesis, Faculty of Agriculture, Alexandria University, Egypt.

Abdul Galil, A.A.; H.A. Basha, S.A.E. Mowafy and M.S. Mohamed. 2003. Effect of phosphorus addition on the response of four wheat cultivars to $\mathrm{N}$ fertilization level under sandy conditions. Minufiya J. Agric. Res. 28: 1- 22.

Abo-Shataia, A.M.; A.A. Abd EL-Gawad, A.K. Abd EL-Haleem and S.F. Habbasha. 2001. Effect of seeding rates and nitrogen fertilization on yield and its attributes of some newly released wheat cultivars. Arab Universities Journal of Agricultural Science. 9: 267-282.

Ahmed, M.Z.D. 2005. Response of wheat to some fertilization treatments and irrigation intervals. M.Sc. Thesis, Faculty of Agriculture, Damanhour Branch, Alexandria University, Egypt. 
Behera, U.K.; B.A. Chougule, R.S. Thakur, K.N. Ruwali, R.C. Bhawsar and H.N. Pandey. 2000. Influence of planting dates and nitrogen levels on yield and quality of durum wheat (Triticum durum). Indian Journal of Agricultural Sciences. 70: 434- 436.

Boehm, D.J.; W.A. Berzonsky and M. Bhattacharya. 2004. Influence of nitrogen fertilization treatments on spring wheat (Triticum aestivum L.) flour characteristics and effect on fresh and frozen dough quality. Cereal Chemistry. 81: 51- 54.

Champien, G.T.; R.J. Froud Williams and J.H. Holland. 1998. Interactions between wheat (Triticum aestivum L.) cultivar, row spacing and density and their effect on weed suppression and crop yield. Am. Appl. Bio., (133): 443-453.

Das, T.K. and N.T. Yaduraju. 1999. Effect of cultivar ear competiton on growth, nutrients uptake and yield of wheat as affected by irrigation and fertilizers. J. Agric. Sci., (133): 45-51.

Echeverria, H.E.; C.A. Navarro and F.H. Andrade. 1992. Nitrogen nutrient of wheat following different crops. J. of Agric. Sci., (118): 157- 163.

Ehdaie, B.; M.R. Shakiba and J.G. Waines. 2001. Sowing date and nitrogen input influence nitrogen-use efficiency in spring bread and durum wheat genotypes. Journal of Plant Nutrition. 24: 899-919.

EL-Eryani, A.A. 2001. Pre-and post-heading growth traits, nitrogen use efficiency and yields of some wheat genotypes as affected by plant density and nitrogen fertilization. Ph. D. Thesis, Faculty of Agriculture, Alexandria University, Egypt.

EL-Genbeehy, M.M.; A.A. Kassem, A.I. Nawar and S.M. Abd Allah. 2001. Effect of nitrogen fertilizer levels and time of application on yield and agronomic characteristics of wheat. Journal of Agriculture Science. 26: 1209-1217.

Ercoli, L and J. Masoni. 1995. Effects of row spacing and orientation on yield and yield components of winter wheat. Agri. Med., (125): 215-221.

Gardner, F.B.; R.B. Peacre and R.L. Michell. 1985. Physiology pf crop plants. Growth development, Chap. 8, pp. 187-208. Iwa State Univ.

Gomez, K.A. and A.A. Gomez. 1984. Statistical Procedures for Agriculture Research. $2^{\text {nd }}$ Ed. John Wiley and Sons. New York, USA.

Hassan, A.A. and A.B. Gaballah. 2000. Response of some wheat cultivars to different levels and sources of nitrogen fertilizers under new reclaimed sandy soil. Zagazig Journal of Agricultural Science. 28: 729-745.

Holland, J.F and D.F. Herridge. 1992. Production of summer crops in northern New South Wales. 2- Effect of tillage and crop rotation on yield of Sorghum. Aust. J. Agric. Res. 43: 123-136.

Jones, U.S. 1987. Fertilizer and soil fertility. $2^{\text {nd }}$ Ed. Clemson University, Clemson, South Carolina.

Khalil, H.E. and M.M. EL-Genbeehy. 2004. Wheat productivity and agronomic traits as influenced by plant populations densities and different nitrogen sources. J. Adv. Agric. Res. (Fac. Agric. Saba Basha), (9): 563-576.

Kupper, G. 2002. Attra. Organic Field Corn Production, pp: 1-15. 
Maqsood, M., A. Ali, Z. Aslam, M. Saeed and S. Ahmad. 2002. Effect of irrigation and nitrogen levels on grain yield and quality of wheat (Triticum aestivum L.). International Journal of Agriculture and Biology. 4: $164-165$.

McColl, D. 1989. Studies on maize (Zea mays L.) at Burda, Malwai II: Yield in short rotations with legumes. Exp. Agric., (25): 367-374.

Nawar, A.I. and H.K. Khalil. 2003. Wheat and one-cut berseem (AL-Fahl) mixtures as source of food and forage. Alex. J. Agric. Res. 48 (3): 4955.

Olsen, J.E.; J.V. Mortensen; L.N. Jorgensen and M.N. Andersen. 2000. Irrigation strategy, nitrogen application and fungicide control in winter wheat on a sandy soil. I. Yield, yield components and nitrogen uptake. Journal of Agricultural Science. 134: 1-11.

Pandey, R.K.; J.W. Maranville and A.Admou. 2001. Tropical wheat response to irrigation and nitrogen in a sahelian environment. I. Grain yield, yield components and water use efficiency. European Journal of Agronomy. 15: 93-105.

Prasad, N.K. and R. Kerketta. 1991. Soil fertility as influenced by different cropping sequences. Ind. J. Agric. Sci., (61): 16-19.

Shalaby, T.A.; M.A. Tabl, A.M. Omar and A.M. Abu EL- Ela. 1996. Response of wheat to nitrogen fertilizer under saline conditions. Journal of Agricultural Research. 22: 376-386.

Sharaan, A.N. and F.S. Abd EL-Samie. 1999. Response of wheat varieties to some environmental influence. 1. Effect of seeding rates and $\mathrm{N}$ fertilization levels on growth and yield of two wheat varieties (Triticum aestivum L.). Annals of Agricultural Science. 44: 589-601.

Sieling, K.; C. Stahl; C. Winkelmann and O. Christen. 2005. Growth and yield of winter wheat in the first three years of a monoculture under varying $\mathrm{N}$ fertilization in NW Germany. European Journal of Agronomy. 22: 7184.

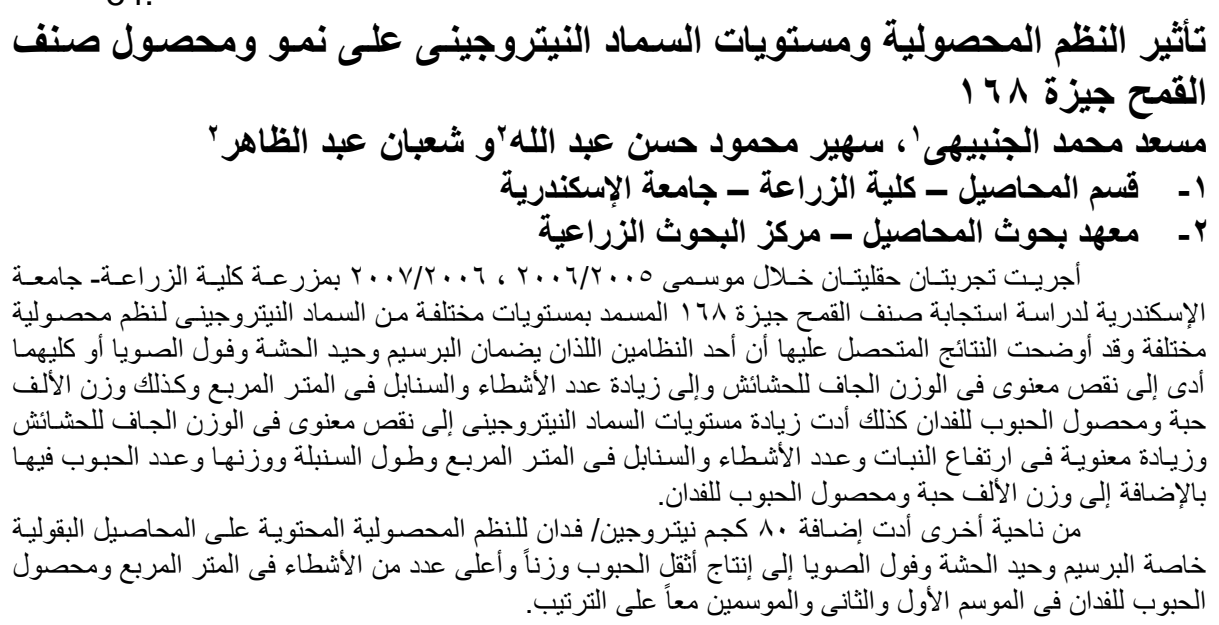


Table (1): Means of weeds dry weight and wheat growth characters as affected by cropping systems and nitrogen levels in the two seasons:

\begin{tabular}{|c|c|c|c|c|c|c|c|c|c|c|}
\hline \multirow{2}{*}{ Treatments } & \multicolumn{2}{|c|}{ Weeds dry weight $(\mathrm{g})$} & \multicolumn{2}{|c|}{$\begin{array}{c}\text { No. of days to } 50 \% \\
\text { Heading }\end{array}$} & \multicolumn{2}{|c|}{ Plant height (cm) } & \multicolumn{2}{|c|}{ No. of tillers $/ \mathbf{m}^{2}$} & \multicolumn{2}{|c|}{ No. of spikes/ $\mathrm{m}^{2}$} \\
\hline & $2005 / 06$ & $2006 / 07$ & $2005 / 06$ & $2006 / 07$ & $2005 / 06$ & $2006 / 07$ & $2005 / 06$ & $2006 / 07$ & $2005 / 06$ & $2006 / 07$ \\
\hline $\begin{array}{l}\text { Cropping systems } \\
\text { Maize-wheat }\left(\mathrm{S}_{1}\right) \\
\text { Maize-B-Wheat }\left(\mathrm{S}_{2}\right) \\
\text { Sun-Fom- Wheat }\left(\mathrm{S}_{3}\right) \\
\text { So-B-Wheat }\left(\mathrm{S}_{4}\right)\end{array}$ & $\begin{array}{l}79.43^{a^{*}} \\
64.07^{b} \\
84.27^{a} \\
51.46^{b}\end{array}$ & $\begin{array}{l}78.73^{a} \\
41.15^{c} \\
74.27^{b} \\
40.64^{c}\end{array}$ & $\begin{array}{l}89.53^{a} \\
88.16^{a} \\
89.26^{a} \\
88.00^{a}\end{array}$ & $\begin{array}{l}86.93^{a} \\
87.60^{a} \\
86.87^{a} \\
86.42^{a}\end{array} \mid$ & $\begin{array}{l}121.75^{a} \\
121.29^{a} \\
120.82^{a} \\
120.54^{a}\end{array}$ & $\begin{array}{l}117.09^{a} \\
118.33^{a} \\
117.99^{a} \\
117.79^{a}\end{array}$ & $\begin{array}{l}398.78^{\mathrm{b}} \\
419.67^{\mathrm{a}} \\
399.56^{\mathrm{ab}} \\
428.37^{\mathrm{a}}\end{array}$ & $\begin{array}{l}388.75^{\mathrm{b}} \\
409.89^{\mathrm{a}} \\
389.52^{\mathrm{b}} \\
418.17^{\mathrm{a}}\end{array}$ & $\begin{array}{l}388.86^{\mathrm{b}} \\
411.46^{\mathrm{a}} \\
378.55^{\mathrm{b}} \\
429.43^{\mathrm{a}}\end{array}$ & $\begin{array}{l}388.31^{b} \\
409.63^{b} \\
389.95^{b} \\
418.45^{a}\end{array}$ \\
\hline L.S.D.0.05 & 13.42 & 2.83 & N.S & N.S & N.S & N.S & 20.61 & 16.86 & 22.85 & 16.14 \\
\hline $\begin{array}{l}\text { Nitrogen Levels: } \\
40 \mathrm{~kg} / \mathrm{fed} . \\
60 \mathrm{~kg} / \mathrm{fed} . \\
80 \mathrm{~kg} / \mathrm{fed} .\end{array}$ & $\begin{array}{l}75.87^{a} \\
70.72^{a} \\
62.00^{b}\end{array}$ & $\begin{array}{l}63.91^{\mathrm{a}} \\
60.56^{\mathrm{b}} \\
51.62^{\mathrm{c}}\end{array}$ & $\begin{array}{l}89.92^{a} \\
88.63^{a} \\
87.66^{a}\end{array}$ & $\begin{array}{l}89.95^{a} \\
89.36^{a} \\
88.57^{a}\end{array}$ & $\begin{array}{l}117.39^{c} \\
121.21^{b} \\
124.71^{a}\end{array}$ & $\begin{array}{l}114.45^{c} \\
117.67^{b} \\
121.27^{a}\end{array}$ & $\begin{array}{l}397.11^{\mathrm{c}} \\
412.69^{\mathrm{b}} \\
443.61^{\mathrm{a}}\end{array}$ & $\begin{array}{l}382.71^{\mathrm{c}} \\
400.31^{\mathrm{b}} \\
421.73^{\mathrm{a}}\end{array}$ & $\begin{array}{l}384.76^{c} \\
401.92^{b} \\
419.55^{a}\end{array}$ & $\begin{array}{l}377.71^{\mathrm{c}} \\
395.31^{\mathrm{b}} \\
416.78^{\mathrm{a}}\end{array}$ \\
\hline L.S.D.0.05 & 6.93 & 2.68 & N.S & N.S & 1.01 & 0.63 & 2.94 & 3.95 & 2.96 & 2.95 \\
\hline
\end{tabular}

Fom = fodder maize, $B=$ one cut berseem , Sun = Sunflower , So = Soybean

* Means within the same column followed by the same letter(s) are not significantly different according to L.S.D. at 0.05 probability level. 
Table (2): Means of wheat yield and yield components as affected by cropping systems and nitrogen levels in the

\begin{tabular}{|c|c|c|c|c|c|c|c|c|c|c|c|c|}
\hline \multirow[t]{2}{*}{ Treatments } & \multicolumn{2}{|c|}{ Spike length $(\mathrm{cm})$} & \multicolumn{2}{|c|}{$\begin{array}{c}\text { Spike grain weight } \\
(\mathrm{g})\end{array}$} & \multicolumn{2}{|c|}{$\begin{array}{l}\text { No. of grains/ } \\
\text { spikes }\end{array}$} & \multicolumn{2}{|c|}{$\begin{array}{c}\text { 1000-grain weight } \\
(\mathrm{g})\end{array}$} & \multicolumn{2}{|c|}{$\begin{array}{l}\text { Straw yield } \\
\text { (ton/ fed.) }\end{array}$} & \multicolumn{2}{|c|}{$\begin{array}{l}\text { Grain yield } \\
\text { (ardab/ fed) }\end{array}$} \\
\hline & $2005 / 06$ & $2006 / 07$ & 2005/06 & $2006 / 07$ & $2005 / 06$ & $2006 / 07$ & $2005 / 06$ & $2006 / 07$ & $2005 / 06$ & $2006 / 07$ & $2005 / 06$ & $2006 / 07$ \\
\hline \multicolumn{13}{|c|}{ Cropping systems } \\
\hline $\begin{array}{l}\text { Maize-wheat } \\
\left(\mathrm{S}_{1}\right)\end{array}$ & $11.49 \mathrm{a}^{*}$ & $12.45^{a}$ & $1.965^{\mathrm{a}}$ & $1.765^{\mathrm{a}}$ & $42.70^{a}$ & $37.70^{a}$ & $45.17^{b}$ & $49.29^{b}$ & $4.69^{a}$ & $4.08^{a}$ & $19.87^{c}$ & $19.35^{c}$ \\
\hline $\begin{array}{l}\text { Maize-B- } \\
\text { Wheat }\left(\mathrm{S}_{2}\right)\end{array}$ & $11.65^{a}$ & $12.83^{a}$ & $1.968^{a}$ & $1.769^{a}$ & $40.75^{a}$ & $37.13^{a}$ & $51.24^{\mathrm{a}}$ & $52.80^{a}$ & $4.76^{a}$ & $4.18^{a}$ & $21.19^{b}$ & $20.16^{b}$ \\
\hline $\begin{array}{l}\text { Sun-Fom- } \\
\left.\text { Wheat(S }{ }_{3}\right)\end{array}$ & $11.56^{a}$ & $12.50^{a}$ & $1.965^{a}$ & $1.805^{a}$ & $41.90^{a}$ & $38.32^{a}$ & $46.80^{\mathrm{b}}$ & $48.20^{b}$ & $4.72^{a}$ & $4.09^{a}$ & $19.76^{c}$ & $18.99^{c}$ \\
\hline $\begin{array}{l}\text { So-B-Wheat } \\
\left(\mathrm{S}_{4}\right)\end{array}$ & $11.71^{a}$ & $12.52^{\mathrm{a}}$ & $1.969^{a}$ & $1.775^{\mathrm{a}}$ & $40.50^{a}$ & $37.31^{a}$ & $53.43^{a}$ & $53.47^{a}$ & $4.74^{\mathrm{a}}$ & $4.15^{\mathrm{a}}$ & $21.92^{\mathrm{a}}$ & $20.75^{a}$ \\
\hline L.S.D. 0.05 & N.S. & N.S. & N.S. & N.S. & N.S. & N.S. & 2.5 & 3.15 & N.S. & N.S. & 0.43 & 0.50 \\
\hline \multicolumn{13}{|c|}{ Nitrogen Levels: } \\
\hline $40 \mathrm{~kg} / \mathrm{fed}$. & $11.23^{c}$ & $12.30^{b}$ & $1.907^{c}$ & $1.755^{\mathrm{b}}$ & $39.40^{c}$ & $35.38^{c}$ & $47.09^{c}$ & $48.70^{c}$ & $4.68^{a}$ & $4.09^{a}$ & $20.05^{c}$ & $19.21^{\mathrm{c}}$ \\
\hline $60 \mathrm{~kg} / \mathrm{fed}$. & $11.72^{\mathrm{b}}$ & $12.67^{a}$ & $1.955^{\mathrm{b}}$ & $1.765^{\mathrm{ab}}$ & $41.00^{\mathrm{b}}$ & $36.68^{b}$ & $49.66^{b}$ & $51.20^{\mathrm{b}}$ & $4.72^{a}$ & $4.12^{a}$ & $20.58^{b}$ & $19.73^{b}$ \\
\hline $80 \mathrm{~kg} /$ fed. & $11.84^{a}$ & $12.76^{a}$ & $1.977^{\mathrm{a}}$ & $1.775^{\mathrm{a}}$ & $43.93^{a}$ & $38.20^{\mathrm{a}}$ & $50.74^{a}$ & $52.93^{a}$ & $4.78^{a}$ & $4.16^{\mathrm{a}}$ & $21.27^{a}$ & $20.61^{a}$ \\
\hline L.S.D.0.05 & 0.12 & 0.14 & 0.21 & 0.17 & 0.55 & 0.49 & 0.11 & 0.38 & N.S. & N.S. & 0.16 & 0.12 \\
\hline
\end{tabular}

Fom = fodder maize, $B=$ one cut berseem, Sun $=$ Sunflower, So $=$ Soybean
* Means within the same column followed by the same letter(s) are not significantly different according to L.S.D. at 0.05 probability level. 